\title{
Tephra, tephrochronology and archaeology - a (re-)view from Northern Europe
}

\author{
Felix Riede ${ }^{1 *}$ and Mads Bakken Thastrup ${ }^{1,2}$
}

\begin{abstract}
Volcanic eruptions are often, although by no means always, associated with a profuse output of fine pyroclastic material, tephra. While residence time in the atmosphere of the very finest of these particles can be substantial, the deposition of the bulk of volcanic ejecta can be considered instantaneous from a geological, archaeological, and evolutionary perspective. Often these volcanic products can be identified by various chemical and non-chemical means and if the eruption date is known, the occurrence of tephra from a given eruption in stratigraphic sequences provides a powerful means of dating such deposits, or of refining available dating schemes. Furthermore, the occurrence of tephra from the same eruption across sites, regions and in various types of depositional contexts (ice-cores, terrestrial, marine, cultural) holds the potential of linking and thus elucidating the tempi and causes of both environmental and cultural change. Recent years have seen considerable advances in tephrochronology studies, especially regarding the detection of macroscopically invisible micro- or cryptotephras. In parallel with the possibility of detecting hitherto invisible tephras over vastly increased areas, the overall potential of tephrochronology as a major dating tool for both palaeoenvironmental scientists and archaeologists is greatly expanded. The aim of this paper is not to be comprehensive, but to provide a brief and timely general review of tephra studies and their methodologies, and to make a case for better linking tephra research to archaeology, all from a primarily Scandinavian perspective. We argue that the identification of tephra in archaeological sediments should, in due time, become as routine as other types of geo-archaeological analyses, especially given that tephra cannot only act as a useful chronostratigraphic marker, but can also play a role in changing patterns of environmental and cultural change at the level of the site or the region. In order to move towards such integration, a series of methodological challenges have to be met. We outline some of these, and provide pointers as to how and where tephrochronologists and archaeologists can work together more closely.
\end{abstract}

Keywords: Tephrochronology, Geochemical fingerprinting, Tephra, Archaeology, Chronology, Electron microprobe, LA-ICPMS

\section{Introduction}

The Law of Superposition and its actualization in the form of stratigraphy constitutes the foundation of archaeological dating, albeit usually in a relative rather than an absolute manner [1-3]. Although many characteristic features within a given stratigraphy (e.g. soil horizons, loess layers) can be used to anchor such sequences in time, the process or processes that cause the formation of such similar layers are often transgressive in time and/or space thus detracting from their general utility as

\footnotetext{
* Correspondence: f.riede@hum.au.dk

'LaPaDiS - Laboratory for Past Disaster Science, Department of Culture \& Society (Materials, Culture \& Heritage), Aarhus University, Campus Moesgård, Højbjerg 8270, Denmark

Full list of author information is available at the end of the article
}

dating and correlation tools. In contrast, the deposition of the loose, pyroclastic volcanic material ejected during a volcanic eruption (tephra) can be considered instantaneous from a geological, evolutionary, and archaeological perspective. The term tephra comes from Greek

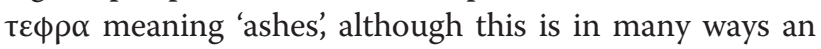
unfortunate misnomer. Volcanic ash is decidedly not the product of organic combustion, but rather it is rock powder generated in an extremely high-powered environment where both native (surface) rocks as well as the magma connected to the eruption itself are torn asunder. Truly distal tephra particles are usually glassy and can retain their characteristic bubble-infused and sharpedged form (Figure 1). Note, however, that the shape,
(C) Chemistry Central 

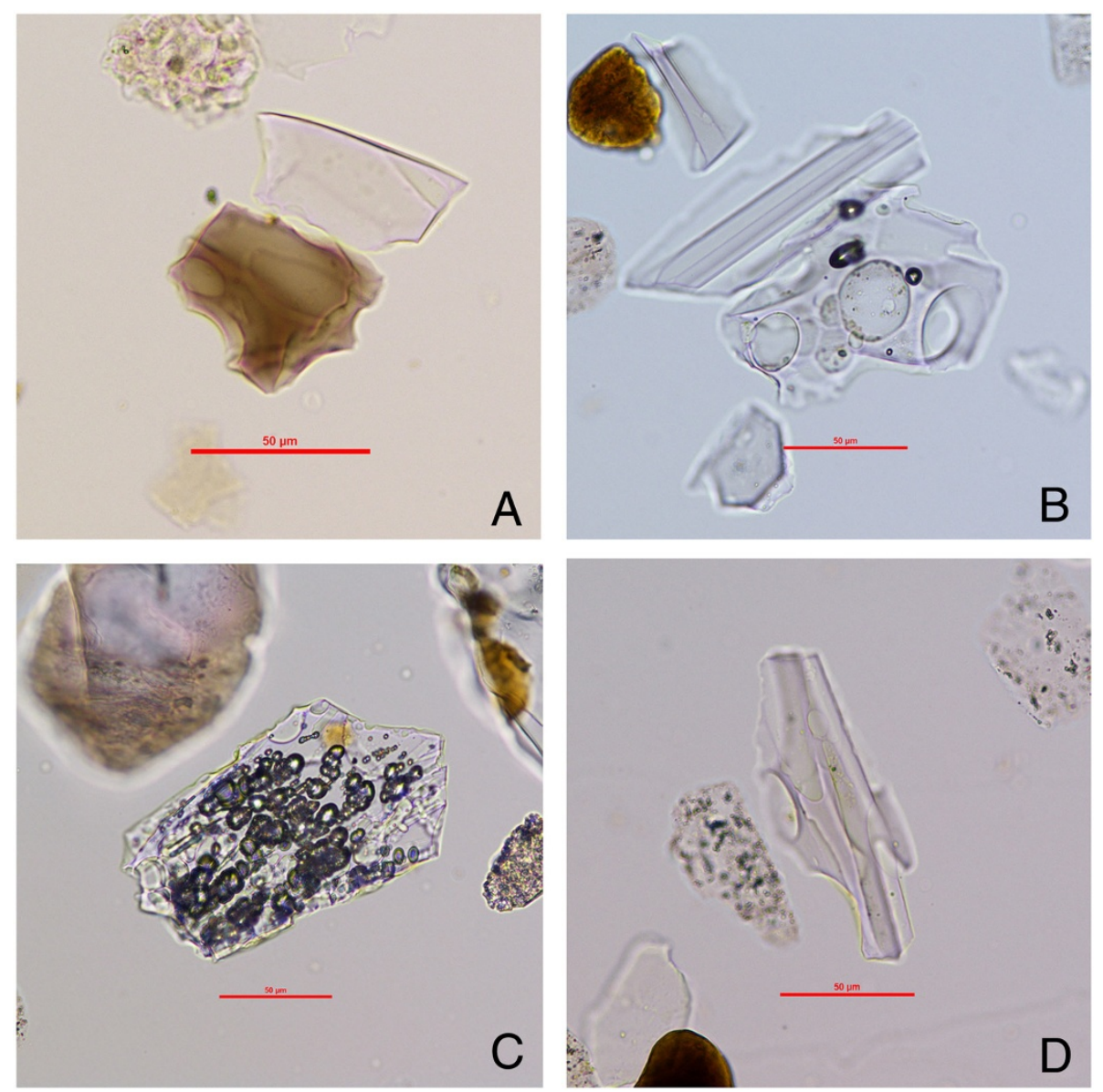

Figure 1 Examples of tephra shards, showing some of the inherent morphological variation. All from a small kettle-hole near Lendum, northern Denmark. The source eruptions remain as yet unidentified.

size, degree of vesicularity, and colour of tephra particles can vary substantially.

Tephra is usually further divided by size classes into ash $(<2 \mathrm{~mm})$, lapilli $(2-64 \mathrm{~mm})$, and bombs or blocks $(>64 \mathrm{~mm})$, the latter of which can reach considerable sizes. The focus of this review is on material at the lower end of this size spectrum and its use as an analytical tool in archaeologically relevant contexts as, first and foremost, chronostratigraphic markers and, secondarily, as possible causal elements in culture-historical change. While the very finest volcanic particles ejected as part of volcanic eruptions can have considerable residence times in the atmosphere as aerosols, the larger particles such as rock fragments, pumice, crystals, and glass tend to fall out already during or shortly after the eruption. They effectively form isochrons. Especially explosive eruptions are associated with a profuse output of such material, and the frequency of such eruptions throughout the Quaternary is substantial [4-6]. Nonetheless, tephrochronological research remains a young field of specialised study. Pioneering near-field work was carried out on
Iceland in the first half of the $20^{\text {th }}$ century by Thorarinsson [7], but it was as late as 1981 that the prospect of a superregional, far-field tephrochronology was first aired [8]. Scientists in the UK swiftly followed Thorarinsson's lead $[9,10]$, and thanks to the many Icelandic eruptions through the millennia $[11,12]$ and a vibrant and growing research community (see http://www. swansea.ac.uk/geography/research/environmentaldynamics group/tephrainquaternaryscience/) there now exists a robust tephrochronological lattice for the Late Pleistocene and Holocene of the north-western Atlantic seaboard [e.g. [13-17] and references therein]. In central Europe, the botanist Firbas [18] suggested already in 1949 that tephra from the Late Glacial Laacher See-eruption could be used as a chronostratigraphic marker for the Allerød chronozone in Europe north of the Alps. This enthusiasm was mirrored by the archaeologist Schwabedissen's [19] remark on how this tephra layer likewise could be used in archaeological investigations both in the near- as well as the far-field of the eruptive centre. Yet, it was first in the 1980s that more extensive distribution maps for the Laacher 
See tephra were presented [20], and more recent still that such data are updated and made available interactively [21].

In general, tephrochronological studies have seen a steep rise over the last two decades (Figure 2). This, we argue, is at least in part due to the development of improved protocols for the extraction of tephra from its surrounding matrix. This is especially relevant for distal occurrences, where volcanic particles are only to be found as crypto- or microtephras, i.e. where they are invisible to the naked eye and cannot be readily detected in the field. In addition, this rise is also the result of increasingly precise and accurate geochemical methods for identifying or 'fingerprinting' particles from particular eruptions. This is usually done via electron microprobe analysis or, occasionally, other analytical approaches. In brief, tephrochronology thus achieves its greatest utility if and when discrete visible or invisible layers of volcanic particles (a) originate from known-age and short-lived explosive volcanic events that (b) left a widespread deposit of particles, which (c) can be securely identified via petrological and/or geochemical methods. Knowledge of the source of the tephra is not strictly required and several important isochron markers (e.g. the Borrobol Tephra) are only known from distal occurrences. In this way, the study of far-field tephra occurrences also feeds back into the basic study of the eruption frequency/magnitude behaviours of volcanic systems, which in turn has important implications for risk assessments in relation to future eruption events $[16,17]$. Tephrochronology is most commonly used as part of Quaternary scientific studies of environmental change, and offers a unique and powerful way of dating and linking different sites and archive types (ice-cores, terrestrial, marine). If the aim is to make such studies of


Figure 2 The development of tephrochronology as a sub-discipline. Citation-analytical bar charts showing the increase of (A) published items and (B) citations in the Web of Knowledge when the search terms 'tephrochronology' (empty bars) and 'tephrochronology' AND 'archaeology' (filled bars) are employed. Whilst such searches may not accurately reflect the volume of tephra research conducted with archaeological relevance (see discussion in main text), they do suggest that archaeology does remain poorly linked with tephrochronology on the whole. Search date: March $7^{\text {th }}, 2013$. 
environmental change relevant to human societies the method attains its greatest utility if either reliable proxies of human activity can be identified alongside the tephra, or - better still - if the tephra itself can also be identified within relevant archaeological layers.

The volcanological background to tephrochronology as a method, attendant techniques, and regional applications have been summarised a number of times in the last decade [22-29], most recently and extensively by Lowe [30], whose magisterial review article fills no less than 46 pages. The aim of the present and rather shorter paper is therefore not to provide a comprehensive treatment of tephrochronology, but to present, discuss and highlight some of its strengths and limitations in relation to specifically archaeological applications. This paper is written from a primarily Northern European/Scandinavian perspective (Figure 3); it is in this region that perhaps the longest tradition in tephrochronological research exists, where efforts to put into place regional tephrochronological lattices and cross-linkages between different volcanic zones are furthest advanced, and where exciting recent projects are beginning to apply tephrochronology to the study of culture-historical change [31-41]. Other regions, such as Alaska [42-44], Central [45-48] and South America [49,50], Papua New Guinea [51-53], Japan [54-56], as well as New Zealand $[57,58]$ have equally rich tephrochronological records linked to archaeological issues. Whilst our choice of regional focus then is primary practical - we know the Northern European region best and it has a long, wellresearched record of human occupation - we also believe that this area constitutes an ideal testing ground for elucidating the salient linkages between tephrochronological and archaeological research.



Figure 3 Schematic map of the North Atlantic province and its attendant volcanic centres, their primary output directions, as well as known and potential far-field input (in italics). 


\section{The basics of tephrochronology}

Tephrochronology is the "use of tephra layers as isochrons (time-parallel marker beds) to connect and synchronize sequences and to transfer relative or numerical ages to them using stratigraphy and other tools" ([30]: 111). This section briefly describes the standard analytical protocols for tephrochronological analysis from field to laboratory. It is worth highlighting that at least the initial stages of sampling and sub-sampling are easily integrated with other types of fieldwork, e.g. sampling for pollen, diatoms or the like, or during standard archaeological excavation where samples can conveniently be taken in open profiles. As in any kind of environmental or archaeological fieldwork, profiles or cores should be described in the field, and any samples duly labelled. Sampling from open profiles is preferable, as sampling with a corer may twist, compact, or otherwise compromise the intactness of the targeted layers. In addition, the general layer structure and possible taphonomic disturbances can be better assessed already in the field when profiles of some length are exposed.

Once the core or block sample is taken, a variety of techniques for an initial identification of the presence/ absence of tephra particles is available: magnetic susceptibility, remanent magnetization, X-radiography, scanning X-ray analytical microscopy, spectrophotometry, high-resolution micropetrography, high-resolution trace element analysis via instrumental neutron activation analysis (INAA), as well as less advanced measurements such as particle size distribution, total organic carbon, and loss-on-ignition (see references [28,30] for details). A particularly useful initial range-finding technique is core scanning by $\mathrm{X}$-ray fluorescence (XRF). This fast method has been reported to work well for detecting considerable $\left(>1000\right.$ shards $\left./ \mathrm{cm}^{3}\right)$ spikes of especially basaltic tephras, but smaller tephra peaks of rhyolitic composition are less well detected [59]. XRF core scanning should thus be used in conjunction with the manual range-finding approach described below, and arguably has its greatest strength in allowing the identification of broad areas with high and mixed shards concentrations, i.e. as an exclusion tool.

Extraction protocols best suited for separating tephra particles form their surrounding matrix depend on the nature of said matrix. When dealing with ombrogenous matrices such as peats ashing alone or in combination with acid digestion usually suffices [29]. Current best practice for extraction of tephra from mineral-rich sediments is the physical density-separation method described by Turney [60] and further refined with important down-stream improvements by Blockely et al. [61]. This method is based on the initial concentration of shards in each sample via ashing and sieving, followed by flotation of particles in a heavy liquid, usually sodium polytungstate (SPT) at $2.5 \mathrm{~g} \mathrm{~cm}^{-3}$. It is important to note that if tephra samples are prepared for geochemical analysis they should be neither ashed nor should they come into lengthy contact with corrosive chemicals, which has been shown to significantly but unsystematically alter the chemical composition of the glass shards. Such corrosion makes the correct geochemical identification and correlation of the extracted tephra difficult if not impossible and a modified extraction procedure needs to be followed [61]. The useful protocol summaries of Swindles et al. [29], Turney [60], and Blockley and colleagues [61] lay out the guidelines for these complementary methods.

As the search for tephra via physical separation can be time-consuming, initial subsampling bins should be chosen at range-finding intervals contingent on overall sequence length. For shorter, usually terrestrial stratigraphies, range-finding bins of 5 or $10 \mathrm{~cm}$ are appropriate. Once tephra has been located in these bins, tighter sampling can commence at $1 \mathrm{~cm}$ intervals. Even greater precision can be achieved if, for instance, varved lake sequences are investigated, where in principle seasonally differentiated tephra deposition can be elucidated [62].

A more detailed counting of shards, reported as shards/g or shards $/ \mathrm{cm}^{3}$ sediment, follows the initial establishment of tephra presence. It is worth noting that true isochrones can reach shard concentrations of several thousands per $\mathrm{g}$ and still remain invisible to the naked eye. Once tephra peaks are securely identified and counted - often against a scatter canvas of occasionally rather substantial background occurrences - shard extraction can proceed. Shards are mounted in Canada balsam, Glycerol or Euparal ${ }^{\mathrm{m}}$ depending on the amount of residual biogenic silica after extraction. Again, Blockley and colleagues conveniently describe this protocol, now widely used by researchers in Europe and elsewhere, in greater detail [61]. Already at the stage of identifying and counting, shard morphology as seen under an optical or scanning electron microscope (SEM) can be used in conjunction with the stratigraphic position of the sample to make tentative suggestions about the particle source. However, many eruptions produce similar-looking shards or are multi-phased thus producing a variety of shard types. Tephra isochrons containing many shards can also contain material from several eruptions closely spaced in age. Visual inspection alone is therefore never enough for a secure identification.

In order to correlate a given tephra deposit securely to others, and ideally to a known source, geochemical fingerprinting is used. The most common analytical procedure is to quantify the major elemental composition of the sample via an electron microprobe (EMP). Prior to the widespread availability of this technique, simpler and cruder methods such as heavy minerals counting and 
shard refractive index were used to identify particular eruptions. These techniques are still commonly encountered in studies whose primary focus is not tephrochronology, but where such an identification still serves the purpose of anchoring a given sequence in time (e.g. pedological and palynological investigations, e.g. [63-66]). When even the resolution of the EMP does not suffice to distinguish between the different eruptions of the same volcanic zone as for instance the many Pleistocene and Holocene Icelandic eruptions [12] - laser ablation-inductively coupled plasma mass spectrometry (LA-ICPMS) is now being taken into use to investigate rare-earth element and trace elemental compositions $[67,68]$.

\section{Tephrochronology and archaeology}

Archaeologists have long been aware of the potential utility of tephra isochrons as dating tools. In addition, volcanic eruptions are regularly considered as prime movers or contributing agents in cultural changes documented in the archaeological record (see, for instance, [45,69-72]). Yet, systematically looking for tephra - especially for cryptotephra - in archaeological stratigraphies is not or at least not yet part of the standard toolkit of archaeologists. The following section uses a series of case studies to highlight the problems with and potential benefits of such integration, and to emphasise some of the challenges when looking for and dealing with tephra deposits embedded in humanly modified or generated strata. Rather than comprehensively reflecting current work in tephrochronology, the case studies discussed here are intended to illustrate the potentials and pitfalls of tephra studies specifically in relation to or performed at archaeological sites. As Housley et al. note "the ability of cryptotephra to survive in archaeological contexts is not well documented" ([73]: 708-9), and each case study discussed here offers particular lessons and insights with regard to the preservation and detection of tephra layers and of, in particular, cryptotephra layers in archaeological sites.

\section{Dosenmoor, Germany}

The Dosenmoor raised bog is located in SchleswigHolstein (northern Germany) at 54.131667/10.019444. It is well-studied from a palaeoenvironmental perspective (see, for instance, reference [73]). Important from the perspective of this review is the fact that the site has been the repeated subject of independent archaeological [74], palynological [75], as well as tephrochronological $[76,77]$ investigations at different points in time. Beginning with the most recent study, van den Bogaard and Schmincke were, in 2002, able to successfully identify 13 discrete tephra layers in a core sequence c. $7.5 \mathrm{~m}$ long. Two parallel cores were investigated at this point, one from the centre and one from the margin of the bog, and, importantly, there was no complete correspondence between the two sequences. While this difference has never been systematically investigated it suggests that different deposition processes or perhaps the deposition of airfall tephra at different times of the year has some influence on where within a single basin the material finally is emplaced, a pattern since also observed elsewhere in northern Europe [78]. Nonetheless, many of these tephras could be identified, and they have provided important links between palaeoenvironmental records across the North Atlantic, as well as acting as highprecision chronological markers for the Dosenmoor sequence itself.

A previous tephrochronological study, published in 1994, likewise succeeded in identifying tephras, albeit only three [77]. Of these, two were suggested via remnant magnetisation, whilst one was securely identified through EMP fingerprinting to be the important Hekla 3 Tephra. In all these studies, the tephra layers provided useful chronological structure to the interpretation of the site's pollen record. Interestingly, however, these analyses appear to have overlooked an earlier pollen analytical investigation at the site, conducted in the 1970s [75]. This work was clearly able to identify some of same pollen zone and their boundaries (Figure 4). Importantly for us, this early pollen analysis was carried out in conjunction with archaeological investigations focused on a site of the enigmatic Mesolithic Kongemose culture [74], which is rarely found in this part of southern Scandinavia [79], and the pollen cores did in fact also contains direct traces of human activity in the form of embedded flint artefacts. None of the early studies included, understandably enough, a tephrochronological element.

We include the Dosenmoor case study here not so much as an example of where tephrochronology has been applied in relation to archaeological investigations, but rather where it has not been applied. The history of the Dosenmoor case study serves to stress two points. First, the dramatic methodological developments in tephrochronology over, in particular, the last ten years make the investigation of new sites but also the reinvestigation of old cores a worthwhile endeavour. It is also worth noting that neither core scanning XRF nor density separation methods for detecting and extracting tephra were apparently used in any of these studies at Dosenmoor. The major methodological advances in tephrochronology outlined in the previous section were implemented only after these studies were completed. One can thus only speculate on how many additional tephra layers one may be able to identify if this sequence was to be the subject of renewed analysis. Second, tephras are of interest to many stakeholders, and costly fieldwork should integrate as many of these interests as possible. We cannot know whether the pollen core investigated during the 1970 contained any tephra at all, 


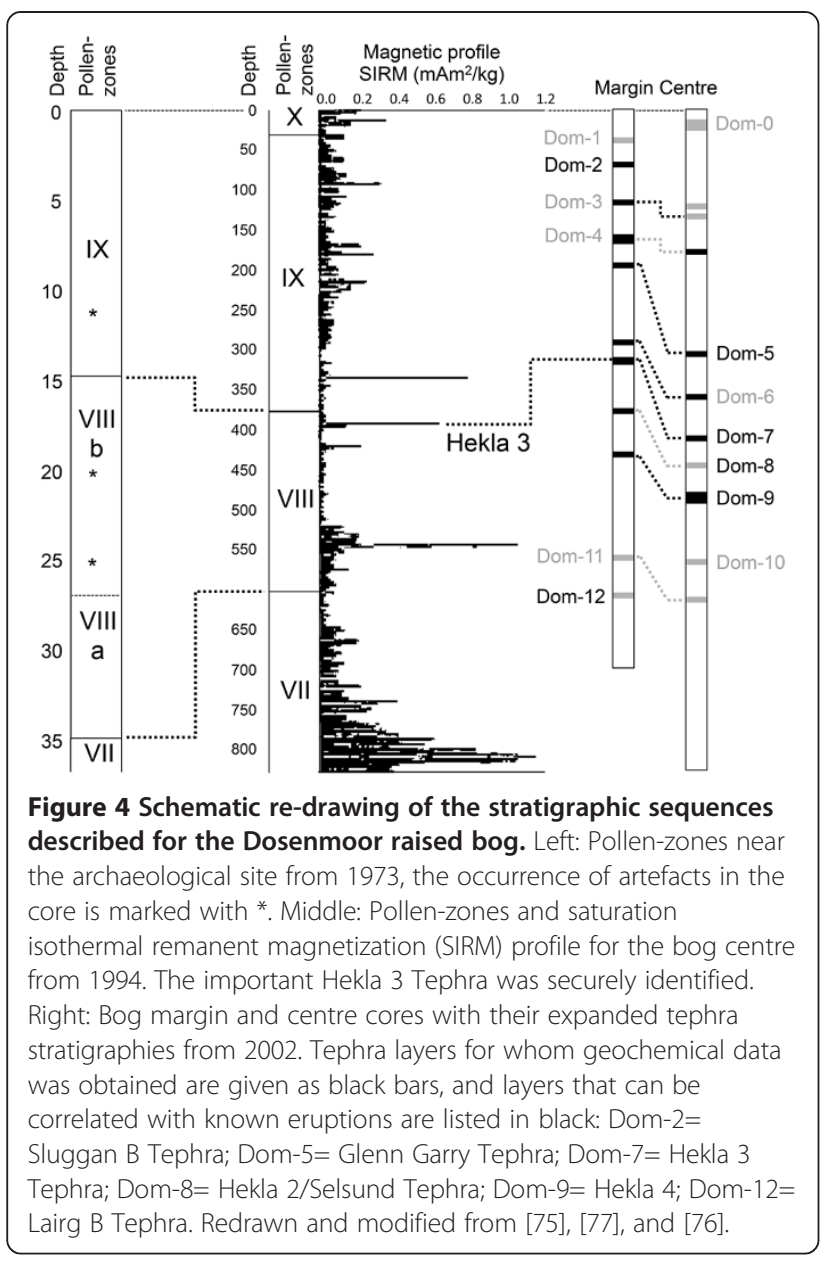

but if bog centre and margin can be linked to human occupation areas through step-wise sampling, tephrochronology can be made more directly relevant also to archaeological investigations - the latter are in as much pressing need for age control and cross-regional correlation as the environmental sciences.

\section{Ahrenshöft LA 58D, Germany}

Much like the Dosenmoor, the site of Ahrenshöft (Schleswig-Holstein, northern Germany, 54.565833/9.108056) has a lengthy history of investigation. There are numerous clusters of Late Glacial archaeological material in the area $[80,81]$, effectively hugging the shores of a palaeolake. Excavation at one of these clusters (LA 73) has provided, for the first time, stratigraphically separated occupation evidence from the early, so-called 'classic' and the later, socalled 'Havelte' phases of the Hamburgian culture [82]. This culture is associated with the human pioneer recolonisation of northern Europe after the last ice age. It is most famously known from the excavations of Alfred Rust in the Ahrensburg Tunnelvalley in the first half of the $20^{\text {th }}$ century, where abundant organic remains were recovered alongside lithic material $[83,84]$. The Hamburgian culture is, however, also known from Holland [85], Poland [86,87], Denmark [88,89], and perhaps even as far afield as Scotland [90]. Whilst a fairly substantial suite of radiocarbon dates is available for this techno-complex [91,92], the individual dates are of highly variable quality and context, and the majority of sites lack absolute dates due to overwhelmingly poor organic preservation at most sites. Accurately dating sites and correlating between them is thus an important research priority. With this in mind, an attempt was made to include tephrochronological investigations as part of recent renewed excavation at the locale of Ahrenshöft LA 58D [93,94].

Three separate column samples consisting of one or several overlapping block sampling tins were taken over two consecutive field seasons (Figure 5). The maximum depth of the block samples was $90 \mathrm{~cm}$, and the maximum distance between these samples no more than $5 \mathrm{~m}$. While, unfortunately, no Late Glacial tephras directly relevant to the dating of the archaeological horizons at the site were discovered, the analysis nonetheless yielded several important results. First, one of the four samples practically yielded no tephra other than faint background traces. Of the remaining two, one sample seemed to show a clear peak some way down the profile during the $5 \mathrm{~cm}$ range-finding exercise, but this peak could not be substantiated during high-resolution $1 \mathrm{~cm}$-interval subsampling. The final column produced perhaps the least surprising result of a shard concentration that rises towards the modern land surface (Figure 6).

Both major and trace elemental analyses were performed on the Ahrenshöft samples, but neither succeeded in discriminating which eruption or eruptions are in evidence at the site. It is clear from these data that the material derives from the Icelandic Katla system, but there are multiple candidate tephras: the Vedde Ash (rhyolitic fraction; mid-Younger Dryas/GI-1), tephra AF555 (late Younger Dryas/GI-1), and the Suduroy tephra dated to the early Holocene. Whilst the tephrochronological analysis at Ahrenshöft LA 58D by no means succeeded in providing a directly useful isochron for the considerably more ancient human occupation at the site, it did demonstrate that even open-air sites with shallow stratigraphies can yield fairly intact tephra deposits. The clearly complex pattern of ash deposition at the site offers important lessons about the impact of small-scale taphonomic processes and topographic differences on tephra preservation. At Ahrenshöft, areas of lower artefact concentration correlate with areas of better peat preservation as well as with better tephra preservation and vice versa. This implies that humans can be important agents in redistributing and reworking tephra deposits. Tight multiple sampling and intra-site crosschecking is thus recommended when looking for tephras in archaeological sites. 


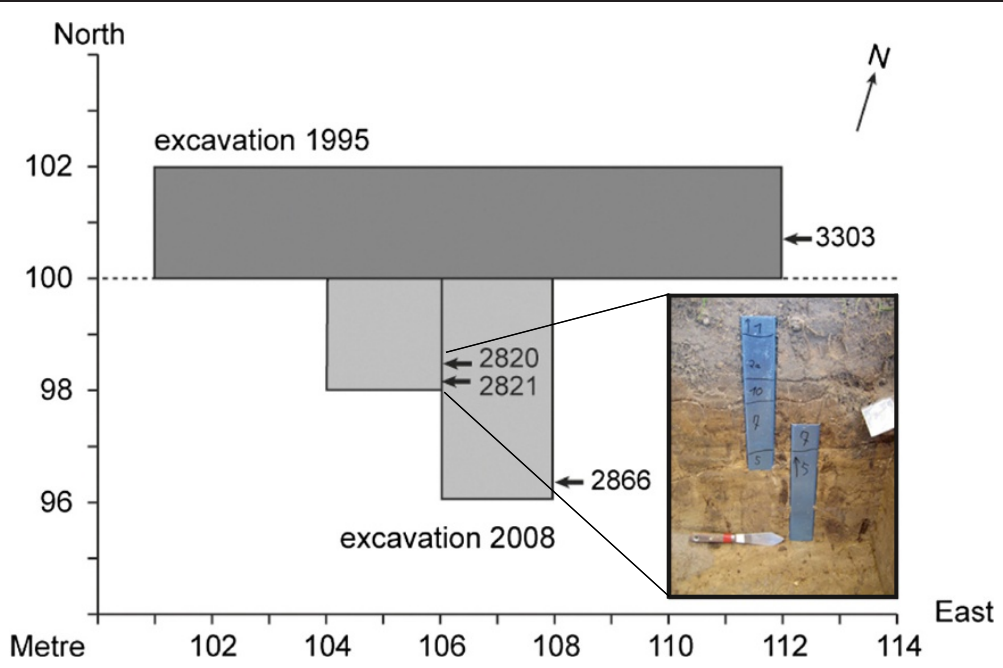

Figure 5 Sampling locations at Ahrenshöft and (inset picture) examples of overlapping block samples prior to removal. The use of block samples allows the transfer of stratigraphic field observations directly onto the block casing. Modified from [93], with permission.

\section{Laacher See tephra - near- and far-field}

Around 13.000 years ago, the Laacher See-volcano (50.416667/7.266667), located in present-day western Germany between the cities of Bonn and Koblenz, erupted cataclysmically [95,96]. As this was the last major eruption from this volcanic zone, the Laacher See-eruption (LSE) remains relatively unknown amongst both archaeologists and the public despite it being classified as a 'super-eruption' [97] and despite it being very well-studied from a volcanological perspective (see, for example, [98-109]). Scoring a Magnitude, $M=6.2$ and an Intensity, I $\geq 11.5$ (see [110] for how to calculate these) it devastated a near-field area of $>1400 \mathrm{~km}^{2}$, and severely impacted the drainage of the River Rhine by fist blocking it and later sending one or several large tsunami-like waves downstream $[111,112]$; river-rafted LSE materials are now known even from the English Channel [113]. Yet, much like at Pompeii, the eruption's thick blanket of pyroclastic material covered and thereby preserved a Late Glacial landscape replete with burned woodlands $[114,115]$, traces of animal movement [116] as well as archaeological sites ranging from miniscule artefact clusters around single short-term campfires [117] to some of the richest locales known from this time [118].

Occurrences of Laacher See-tephra (LST) at some distance from the eruptive centre have been known since the late $19^{\text {th }}$ century [119], and the potential of the LST to provide a major temporal marker for the Allerød chronozone of the Late Glacial became fully evident as additional and more distal occurrences became known in the latter part of the $20^{\text {th }}$ century $[20,120]$. However, even these maps were based on 40 securely identified
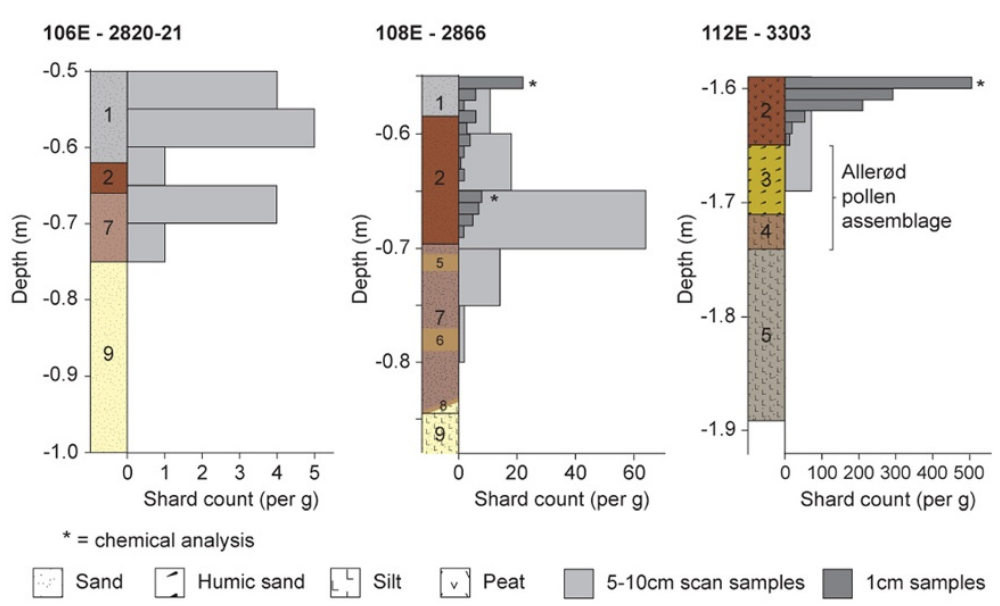

Figure 6 The results obtained at the three closely spaced sampling locations at Ahrenshöft, from [93], with permission. 
data points from 6 countries (see reference 20's Supplementary Table B). Until recently, these best-estimate maps were regularly reproduced in the literature. Renewed efforts to collate an up-to-date body of LST data points has increased the number of occurrences more than tenfold [32]. At the time of writing, 607 discrete LST data points are known, covering eleven countries (Table 1). Collecting these data required a major literature search effort as these occurrences are mentioned across a range of different disciplines - volcanology, geology, soil science, palynology, geography, and archaeology, as well as unpublished grey literature sources (i.e. regional natural resource management agencies, conservation agencies, etc.) - and in nearly as many languages. Important from this review's perspective is that an increasing number of archaeological sites preserving either LST cryptotephra layers or even layers easily seen by the naked eye have also emerged. In fact, some of the best-preserved and most massive farfield LST strata come from archaeological sites (see $[121,122]$ and Figure 7$)$. Whilst not all archaeology associated with LST layers is also directly related to the eruption event, upwards of 20 LST localities do preserve traces of Late Glacial habitation. The general pattern here is that LST caps occupation at these sites, which if at all are first re-occupied many centuries or even millennia later. This observation feeds into broader hypotheses of how this eruption may have impacted flora, fauna, and foragers at that time [123-129].

The Laacher See case study, too, offers useful lessons for the integration of tephrochronological and archaeological research. First, occurrences of relevant tephras are mentioned in many different kinds of texts, and collating them requires considerable and broad desk- and library-based research. Consulting the standard, webbased indices and databases (such as the Web of Science used to generate Figure 2 above!), which reasonably

Table 1 The number of Laacher See tephra (LST) occurrences in Europe

\begin{tabular}{ll}
\hline Country & $\mathbf{N}_{\text {LST }}$ \\
\hline Austria & 2 \\
Belgium & 6 \\
Denmark & 2 \\
France & 100 \\
Germany & 437 \\
Italy & 2 \\
Luxembourg & 13 \\
Netherlands & 6 \\
Poland & 3 \\
Sweden & 2 \\
Switzerland & 34 \\
& 607 \\
\hline
\end{tabular}

cover most natural sciences but perform relatively poorly when it comes to the humanities and smaller non-English language journals, series or monographs, is simply not sufficient. Secondly, when made publically available through community tools such as, for instance, Tephrabase (www. tephrabase.org; see references $[141,142])$ or RHOXTOR [see http://c14.arch.ox.ac.uk/rhoxtor], the resulting distribution maps can be used to evaluate both research biases in these distributions, and to better design future research projects. In the case of the LST, it seems evident, for example, that the eastern limits of the north-eastern fallout lobe are not an accurate reflection of the real fallout distribution, but rather that they reflect a current lack for tephrochronological research in Poland, whose border this distribution follows almost exactly (Figure 8). Consequently, western and northern Poland with its rich Late Glacial archaeology [143-145] may be one of the most promising areas for future research in this line.

\section{Tjørnuvík, Faroe islands}

Tjørnuvík is located on the island of Streymoy, Faroe Islands at 62.289503/-7.148280. The timing of the first human settlements in Faroe Islands has been subject to a fair amount of discussion [146]. The majority of AMS dates indicate that the initial settlement of the Faroe Islands took place between AD 600-900, but as this time interval coincides with a plateau in the calibration curve dating by radiocarbon alone provides only limited resolution. Small islands such as the Faroes are ideal testing grounds - natural experiments of history - for both colonization scenarios and for investigating the impact of humans on previously unmodified landscapes [147-149]. In an exemplary investigation, Hannon and colleagues set out to date the first settlement by combining different proxy analyses: pollen, trace charcoal, macrofossils, diatoms, AMS radiocarbon dating and tephrochronology $[146,150,151]$. Pollen analysis from a valley marsh at Tjørnuvík indicates settlement in the area at AD 650-900, and three tephra horizons were discovered in the investigated stratigraphies. Tjørnuvík A, Tjørnuvík B and the basaltic phase of the landnám tephra (VIIa). The origin and date of Tjørnuvík A derives from an otherwise unrecorded Hekla eruption in the $9^{\text {th }}$ century AD. Tjørnuvík B shows similarities to the 1158 AD eruption of Helka, but radiocarbon dates and stratigraphic position show that this tephra is, in fact, older [151]. The landnám tephra, dated to $\mathrm{AD} 871 \pm 2$ [152], is found above the first settlement indicators clearly demonstrating that human impact on the vegetation predates this event.

The Tjørnuvík case study underlines that environmental proxy analyses, AMS radiocarbon dating, and tephrochronology in judicious combination can significantly strengthen historical ecological conclusions, especially in key periods - such as the Norse expansion in the North 


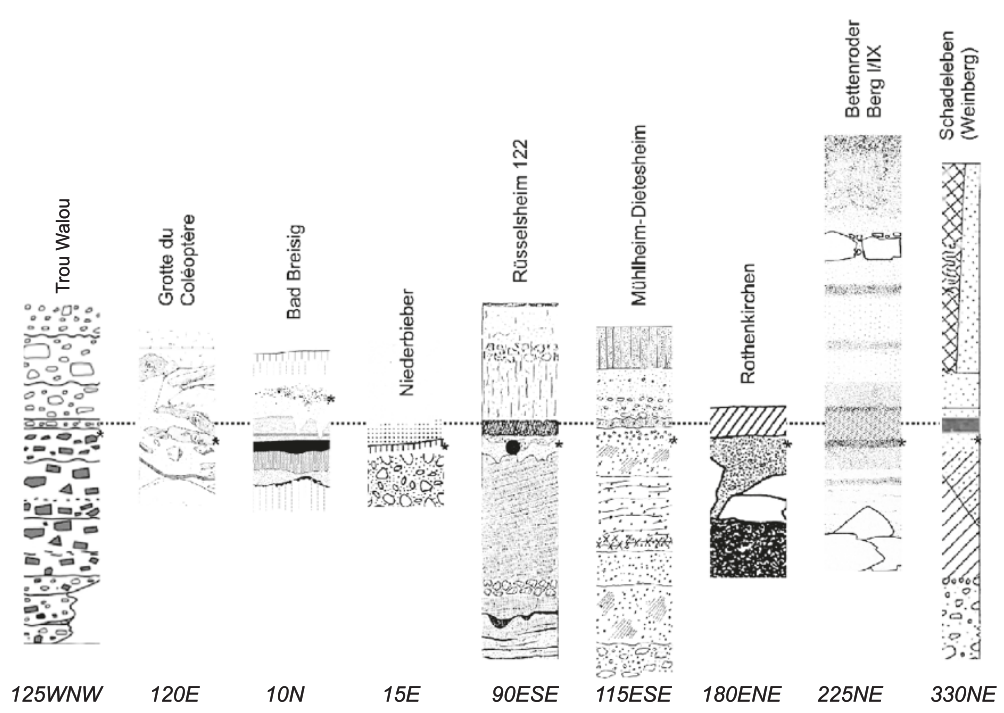

Figure 7 Schematic figure of key archaeological sites that also preserve traces of Laacher See tephra, and (bottom) their distance and compass direction from the eruptive centre. The position of relevant archaeological finds is marked with *. Only at the site of Bad Breisig does relevant Late Glacial archaeology occur above the Laacher See tephra. This small-scale and perhaps exploratory occupation is dated to some time (as much as 200 years) after the eruption [130]. Trou Walou: [131]; Grotte du Coléoptère: [132]; Bad Breisig: [133]; Niederbieber: [134]; Rüsselsheim 122: [135]; Mühlheim-Dietesheim: [136]; Rothenkirchen: [125]; Bettenroder Berg I/IX: [137]; Schadeleben (Weinberg): [122,138-140]. Note that there are additional sites with archaeology and Laacher See-tephra in Belgium (here represented by the stratigraphies of Trou Walou and the Grotte du Coléoptère), the Rhineland (here represented by the stratigraphy of Niederbieber), and in the area around the River Leine (here represented by the stratigraphy of Bettenroder Berg). Site stratigraphies are not to scale.

Atlantic - where plateaus in the calibration curve occur. Yet, one can also note that tephra analysis has not (or not successfully) been applied in similar studies on the Faroes (e.g. [153]), nor are we aware of attempts at extracting tephra from actual archaeological sites on any of the Faroese islands. In our opinion, the full potential of tephrochronology in the Faroe Islands, as elsewhere, will first be realized once we can use tephra to directly cross-link environmental and archaeological sequences.

\section{Borg, Norway}

This final case study does provide an example of how such linkage may be achieved. Balascio and colleagues' combined archaeological and tephrochronological study of the important Iron Age/Viking site of Borg on the Lofoten Islands, Norway (68.25000/13.785833) at present stands as one of the best examples of such interdisciplinary research [154]. The site is characterised by a suite of boat-houses, so-called nausts, belonging to an emerging political stronghold in the area connected to fishing and trade. Indeed, such boat-houses are a key feature of the built environment of Iron Age, Viking and Medieval periods in the North Atlantic, and their somewhat mundane label belies their actual multi-functionality and their importance as locational foci for both economic, military, and political operations in these periods [155-158].

Yet, despite their culture-historical significance, relatively few of these structures are dated absolutely, and a chronological division of the material based on architectural features and size alone only holds limited promise [156]. Balascio and colleagues succeeded in extracting (using the acid digestion protocol) and subsequently geochemically fingerprinting tephra from two strata. This allowed them to constrain the periods of use of the boat-houses at Borg through the use of tephrochronology. Much like at Tjørnuvík, such bracketing again proved particularly useful here given the plateau in the calibration curve around this time, and the generally increased need for chronological precision at this near end of the radiocarbon dating range. Multiple tephra occurrences - here from the well known AD 860 Layer B tephra and later $\mathrm{AD} 1104,1158$, or 1300 candidate Hekla tephras - provided secure temporal anchors in these stratigraphies.

Should one be surprised that tephra was found at this site? The Lofoten have yielded the most complete tephrochronological record in Norway spanning the entire Holocene and part of the Late Glacial [159]. It is interesting to note in this respect that the collaborative effort of Balascio et al. came about more by coincidence than by design (S. Wickler, pers. comm. 23.2.2012): Research into the environmental history of the inner lake Borg (see [160]) was being conducted at the same time as archaeological research at its shores. From there it was only a short step to also apply the tools of tephrochronology - at any rate already part of the former 


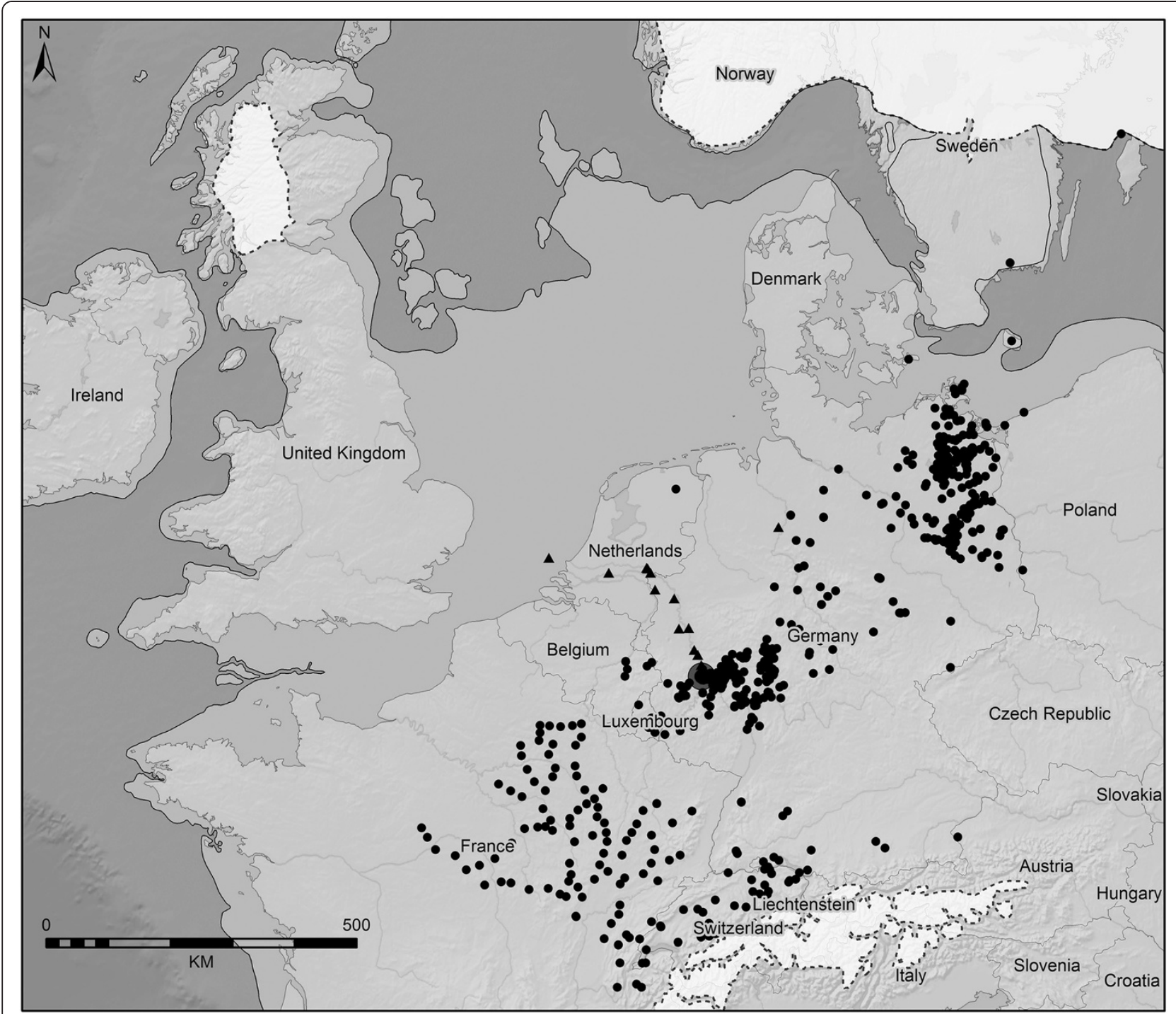

Figure 8 Map of the occurrence of Laacher See tephra in Europe. Note how the currently known distribution follows the German-Polish border. Circles indicate air-fall tephra (often known only from heavy minerals or visual inspection), triangles fluvial deposition. Updated from [21].

project's methodological repertoire - also to the samples from the archaeological site. Whether by coincidence or design, Balascio and colleagues did, encouragingly, succeed in clearly demonstrating "the potential for cryptotephrochronology as a geochronologic tool for archaeologists in Norway" ([154]: 940). The true potential of this new tool will, however, first be realised if and when it has come into use more widely, both in terms of systematically investigated sites and contexts as well as in terms of countries in which it is applied. In addition, lessons from the Ahrenshöft investigation discussed above further suggest that there is also some danger in spotsampling for tephra at archaeological sites: We do not know, therefore, whether the tephras are preserved in layers or lenses at Borg.

\section{Lessons learned and future challenges}

Tephrochronology and, in particular, its cryptotephra extension are still young fields of specialisation. The chance of successful detection of cryptotephras relies above all on stable depositional conditions as found in, for instance, small-to-medium-sized lake basins that preferably lack complex and shifting in- and outflow channels [78]. Most archaeological sites are far from this in terms of depositional context, making the search for preserved tephra layers in such stratigraphies a risky venture. Yet, relatively few types of sites have been sampled, and the number of samples per site has generally been low. Detailed taphonomic observations coupled with closely spaced sampling, however, have demonstrated that there can be substantial variation in the 
preservation of tephras across short distances - both in environmental [78] as well as in archaeological contexts [93]. One of the lessons that can be learned from the case studies presented here is that multiple samples should always be obtained in as systematic a fashion as is possible. Samples from archaeological sites should, if at all possible, be multiple in order to assess layer intactness, and complemented by samples from nearby environmental contexts. It is our recommendation that such parallel sampling should follow a transect strategy from archaeological site (on-site/multiple features or sections) > archaeological site (off-site) > nearest lake/bog (margin) > nearest lake/bog (centre). Whilst costly such a strategy would maximise the chances of finding tephra, would allow environmental reference samples to be obtained, and would make it possible to arrive at both a site-specific as well as, eventually, a more general understanding of how and why tephra preserves in some places but not in others.

Once found, the analysis of tephras from archaeological sites should be handled following the established laboratory and analytical protocols. The interpretation of tephra distributions in and around a given site should be conducted as a collaborative effort between environmental and archaeological specialists. Natural processes alone can move tephra around in profiles, and even create false secondary layers either above or below the actual air-fall event strata $[31,78,161]$. Adding humans to the list of taphonomic agents will not make the interpretation of such layers easier, but it is worth stressing that tephra may, due to it being inorganic, provide a particularly useful (at times perhaps sole) dating tool in archaeological sequences with poor organic preservation.

Where community reference databases are already in place, all resulting data should be submitted to these. We see data sharing as a critical tool for furthering research, especially this kind of work that does not respect current national boundaries. Indeed, one priority for future work aimed at elucidating the relationship between volcanic events and the human past is the establishment of complementary databases on the societal and economic characteristics of the affected groups. Both disaster scientists and volcanologists have assembled sizable databases of volcanic eruptions as well as their impacts in recent times $[4,5,162,163]$. No such databases exist for deeper historical let alone prehistoric times. If, however, the aim is to not only examine volcanic eruptions and their attendant tephra distributions as purely chronological tools, but also to consider the impacts of such events on the affected societies themselves, these databases must be structured around the societies themselves, not the eruption events. This is so, because (a) the effects of eruptions differ markedly in the near- and far-field [164], and (b) because the vulnerability that transforms an initially neutral geological event into a catastrophe is a complex, multivariate measure that is grounded at least as much in the social and historical parameters of the affected communities as in the geophysical parameters of a given event [165-167]. The finding and secure geochemical identification of a given tephra layer is a critical but merely an initial step.

\section{Conclusion}

Precise and accurate chronologies are paramount for studies of past environmental and cultural change. Tephrochronology constitutes a powerful dating tool and "tephra studies have become increasingly important in Quaternary research as the need to provide high-resolution palaeoenvironmental or archaeological records, and to synchronize and date such records, has become an urgent focus" ([30]: 107-8). To date, the vast majority of (crypto-)tephrochronological research has been and still is conducted as part of environmental science, and it is made relevant to archaeology via very effectively providing better-resolved environmental backdrops to cultural changes (e.g. [168]). Yet, to fully unlock the potential of tephrochronology to directly link environmental and cultural sequences, future work should, in our opinion, attempt to more systematically and routinely look for tephra also within archaeological stratigraphies. Whilst recent tephra research projects such as the UK-based, NERCfunded RESET initiative, or the LaPaDiS project funded by the Danish Council for Independent Research | Humanities do contain archaeological work packages, they are, somewhat paradoxically, aimed at linking ancient deep time archaeological records to dated volcanic eruptions via tephra analyses. Tephras of such age are difficult to find even under the best of circumstances. Adding to this, humans are by all accounts effective taphonomic agents, and finding intact tephra layers in occupation sites is a long, albeit not impossible shot $[33,125]$. Projects centred on deep prehistory tend to naturally include strong environmental and/or geological elements, so adding tephrochronology to the methodological repertoire makes good sense. Projects concerned with more recent periods should, we recommend, follow this lead.

One of the aims of this review has been to outline a programme for more collaborative work between earth scientists interested in tephra and archaeologists, and to make an argument for the use of (crypto-)tephra analysis in direct relation to archaeological sites or features. A more balanced integration of tephrochronology and archaeology should include more recent periods as well as later prehistory and the deep times of the Palaeolithic. The historical and Holocene record of volcanic eruptions is better understood than its Pleistocene counterpart, and all things being equal, younger tephras should be better preserved. Joint tephrochronological/archaeological research in historic periods has the potential to 
provide key proof-of-concept case studies for this emerging field. Importantly, numerous researchers also argue that eruptions and their attendant tephra fallout have had important culture-historical consequences, also in historical times (e.g. [169-172]). Tephras do, of course, play a major role in archaeological work on Iceland and the North Atlantic, in Kamchatka, and in other areas known to be volcanically active [37,173-175], but even there, archaeological stratigraphies are rarely investigated for cryptotephras - despite the fact that numerous hypotheses about the direct impact (or otherwise) of past eruptions on the affected societies have been aired [173,176-178]. Yet, finding such temporal markers either in addition to known visible layers or in the absence of previously recognised layers could unlock a tremendous analytical potential:

(1) They would allow many more sites to be dated both accurately and precisely.

(2) They would allow both accurate and precise terminus ante/post quem correlations of local culture-historical sequences over potentially vast expanses of space.

(3) They would facilitate detailed investigations into the potential culture-historical impact of the eruptions themselves or other "collateral" ([179]: 59) environmental changes around them.

(4) In turn, they would also feed back into volcanological research by adding to the total record of known eruptions and their attendant tephra distributions.

Tephra is well known to travel great distances - even across continents [180] - and could thus serve to link not only volcanic zones but also to bind cultural provinces (e.g. the Viking/Norse heartland in Scandinavia, Iceland, Greenland, Faroe Islands and the Atlantic seaboard of the USA; Late Glacial Europe, etc.) together internally, and with each other. The identification of such potential marker horizons in both archaeological and palaeoenvironmental sequences then offers the exciting opportunity for high-resolution comparative studies of the relationship between human societies and environmental changes that avoids the methodological uncertainties otherwise associated with such studies [181].

Whilst rare on a human time-scale, volcanic eruptions are common occurrences over geological, evolutionary, and archaeological time. The human lineage has a strong association with volcanic landscapes [182], and tephrochronology already is a powerful tool in dating the very earliest of archaeological and palaeoanthropological remains [183]. The possibility that larger eruptions may have significantly affected the course of human evolution globally [184-189] and regionally [33,190,191] alone warrants a tight integration of tephrochronology and archaeology. Yet, this review has underlined that the archaeological utility of tephra markers goes well beyond their presence in the geological matrices containing cultural material and well beyond early prehistory into historic times - especially when extended to also cover cryptotephras. In doing so, this review has attempted to summarise and evaluate some of the recent research at the interface between archaeology and tephrochronology. At the same time this paper also flags up the need for a tighter and more systematic integration of these fields of study. Despite the remaining methodological challenges and problems outlined by Lowe [30] the protocols of tephrochronology are now so well-established and mature that the time is right to experiment with sampling from a wider range of not only natural but also cultural deposits (and, importantly, to also report when and ideally why sampling returned negative results). Any structure that captures and preserves airborne material in some form of stratigraphic order - wells, ditches, multi-phase burial mounds, shell-middens, house floor successions, etc. - potentially preserves traces of volcanic ash. Archaeology can play an important role in exploring the range of responses of human societies to climate change in the past, but securely linking environmental to cultural archives is of fundamental importance in order to differentiate between just-so-stories of environmental impacts and the actual, but usually complex causal chains of culture change in the wake of climatic and environmental disturbances [71,192-194].

\section{Abbreviations \\ LA-ICPMS: Laser ablation-inductively coupled plasma mass spectrometry; INAA: Instrumental neutron activation analysis; XRF: X-ray fluorescence; SPT: Sodium polytungstate; SEM: Scanning electron microscope; EMP: Electron microprobe; LST: Laacher See-tephra; LSE: Laacher See- eruption; NERC: Natural Environment Research Council; RESET: Response of humans to abrupt environmental transitions; SIRM: Saturation isothermal remanent magnetization; LaPaDiS: Laboratory for Past Disaster Science.}

\section{Competing interests}

We declare no competing interests.

\section{Authors' contributions}

FR and MBT conceived of and wrote the paper. Both authors read and approved the final manuscript.

\section{Acknowledgements}

FR and MBT are funded through the Danish Agency for Science, Innovation and Technology's Independent Research Council | Humanities grant $11-$ 106336. This paper arose from a joint presentation at the SMIA X Scientific Methods in Archaeology meeting, Aalborg University, Esbjerg (Denmark), September $27^{\text {th }}-29^{\text {th }}, 2012$. We gratefully acknowledge the suggestions of two anonymous reviewers who provided important and constructive comments. All omissions and errors remain ours.

\section{Author details}

"LaPaDiS - Laboratory for Past Disaster Science, Department of Culture \& Society (Materials, Culture \& Heritage), Aarhus University, Campus Moesgård, Højbjerg 8270, Denmark. ${ }^{2}$ Moesgård Museum, Department of Archaeological Science \& Conservation, Højbjerg 8270, Denmark. 
Received: 22 March 2013 Accepted: 10 May 2013

Published: 28 May 2013

\section{References}

1. O'Brien MJ, Lyman RL: Seriation, Stratigraphy, and Index Fossils. The Backbone of Archaeological Dating. New York, NY: Kluwer Academic/Plenum; 1999.

2. Harris EC: Principles of Archaeological Stratigraphy. London: Academic Press; 1989.

3. Holst MK: Complicated Relations and Blind Dating: Formal Analysis of Relative Chronological Structures. In Tools for Constructing Chronologies: Crossing Disciplinary Boundaries. Edited by Buck CE, Millard A. London: Springer; 2004:129-147.

4. Crosweller HS, Arora B, Brown SK, Cottrell E, Deligne NI, Guerrero NO, Hobbs L, Kiyosugi K, Loughlin SC, Lowndes J, Nayembil M, Siebert L, Sparks RSJ, Takarada S, Venzke E: Global database on large magnitude explosive volcanic eruptions (LaMEVE). J App/ Volcanol 2012, 1:4.

5. Bryson RU, Bryson RA, Ruter A: A calibrated radiocarbon database of late Quaternary volcanic eruptions. eEarth Discussions 2006, 1:123-134.

6. Simkin T, Siebert L: Explosive eruptions in space and time: Durations, intervals, and a comparison of the World's active volcanic belts. In Explosive Volcanism: Inception, Evolution, and Hazards. Edited by Boyd FR. Washington, DC: National Academy of Science Press; 1984:110-121.

7. Thorarinsson S: Tefrokronologiska studier på Island. Geogr Ann 1944, 26:1-217.

8. Thorarinsson S: Greetings from Iceland. ash-falls and volcanic aerosols in Scandinavia. Geogr Ann 1981, 63:109-118.

9. Dugmore A: Icelandic volcanic ash in Scotland. Scott Geogr Mag 1989, 105:168-172.

10. Pilcher JR, Hall VA: Towards a tephrochronology for the Holocene of the north of Ireland. Holocene 1992, 2:255-259.

11. Thordarson T, Larsen G: Volcanism in Iceland in historical time: Volcano types, eruption styles and eruptive history. J Geodyn 2007, 43:118-152.

12. Larsen G, Eiríksson J: Late Quaternary terrestrial tephrochronology of Iceland-frequency of explosive eruptions, type and volume of tephra deposits. J Quat Sci 2008, 23:109-120.

13. Pyne-O'Donnell SDF, Blockley SPE, Turney CSM, Lowe JJ: Distal volcanic ash layers in the Lateglacial Interstadial (Gl-1): problems of stratigraphic discrimination. Quat Sci Rev 2008, 27:72-84

14. Hall VA, Pilcher JR: Late-Quaternary Icelandic tephras in Ireland and Great Britain: detection, characterization and usefulness. Holocene 2002, 12:223-230.

15. Wastegård S: Late Quaternary tephrochronology of Sweden: a review. Quat Int 2005, 130:49-62.

16. Swindles GT, Lawson IT, Savov IP, Connor CB, Plunkett G: A 7000 yr perspective on volcanic ash clouds affecting northern Europe. Geology 2011. in press.

17. Lawson IT, Swindles GT, Plunkett G, Greenberg D: The spatial distribution of Holocene cryptotephras in north-west Europe since 7 ka: implications for understanding ash fall events from Icelandic eruptions. Quat Sci Rev 2012, 41:57-66.

18. Firbas F: Spät- und nacheiszeitliche Waldgeschichte Mitteleuropas nördlich der Alpen Erster Band: Allgemeine Waldgeschichte. Jena: Verlag von Gustav Fischer; 1949.

19. Schwabedissen H: Die Federmessergruppen des nordwesteuropäischen Flachlandes: Zur Ausbreitung des Spät-Magdalénien. Neumünster: Karl Wachholtz Verlag GmbH; 1954.

20. van den Bogaard P, Schmincke H-U: Laacher see tephra: a widespread isochronous late Quaternary tephra layer in Central and Northern Europe. Geol Soc Am Bull 1985, 96:1554-1571.

21. Riede F, Bazely O, Newton AJ, Lane CS: A Laacher See-eruption supplement to Tephrabase: investigating distal tephra fallout dynamics. Quat Int 2011, 246:134-144

22. Sarna-Wojcicki AM: Tephrochronology. In Quaternary Geochronology: methods and Applications. Edited by Noller JS, Sowers JM, Lettis WR. Washington, DC: American Geophysical Union; 2000:357-377.

23. Turney CSM, Lowe JJ: Tephrochronology. In Tracking Environmental Change Using Lake Sediments. Volume 1: Basin Analysis, Coring, and Chronological Techniques. Edited by Last WM, Smol PJ. Dordrecht: Kluwer Academic; 2001.

24. Shane P: Tephrochronology: a New Zealand case study. Earth Sci Rev 2000, 49:223-259.

25. Turney CSM, Lowe JJ, Davies SM, Hall V, Lowe DJ, Wastegård S, Hoek WZ, Alloway B: SCOTAV and INTIMATE Members: Tephrochronology of Last Termination Sequences in Europe: a protocol for improved analytical precision and robust correlation procedures (a joint SCOTAV-INTIMATE proposal). J Quat Sci 2004, 19:111-120.
26. Wulf $\mathrm{S}, \mathrm{Kraml} \mathrm{M}$, Keller J: Towards a detailed distal tephrostratigraphy in the Central Mediterranean: The last 20,000 yrs record of Lago Grande di Monticchio. J Volcanol Geotherm Res 2008, 177:118-132.

27. Lowe DJ: Globalization of tephrochronology: new views from Australasia. Prog Phys Geogr 2008, 32:311-335

28. Alloway BV, Larsen G, Lowe DJ, Shane PAR, Westgate JA: QUATERNARY STRATIGRAPHY | Tephrochronology. In Encyclopedia of Quaternary Science. Edited by Scott AE. Oxford: Elsevier; 2007:2869-2898.

29. Swindles GT, De Vleeschouwer F, Plunkett G: Dating peat profiles using tephra: stratigraphy, geochemistry and chronology. Mires \& Peat 2010, 7:1-9.

30. Lowe DJ: Tephrochronology and its application: a review. Quat Geochronol 2011, 6:107-153.

31. Davies SM, Abbott PM, Pearce NJG, Wastegård S, Blockley SPE: Integrating the INTIMATE records using tephrochronology: rising to the challenge. Quat Sci Rev 2012, 36:11-27.

32. Riede F: A Laacher See-eruption supplement to Tephrabase. A revised tephra fallout map and new geochemical data. Quat Int 2012, 279-280:403.

33. Lowe J, et al: Volcanic ash layers illuminate the resilience of Neanderthals and early modern humans to natural hazards. Proc Natl Acad Sci 2012, 109:13532-13537.

34. Lane CS, Andrič M, Cullen VL, Blockley SPE: The occurrence of distal Icelandic and Italian tephra in the Lateglacial of Lake Bled, Slovenia. Quat Sci Rev 2011, 30:1013-1018.

35. Lane CS, Blockley SPE, Lotter AF, Finsinger W, Filippi ML, Matthews IP: A regional tephrostratigraphic framework for central and southern European climate archives during the Last Glacial to Interglacial transition: comparisons north and south of the Alps. Quat Sci Rev 2012, 36:50-58.

36. Lane CS, Blockley SPE, Ramsey CB, Lotter AF: Tephrochronology and absolute centennial scale synchronisation of European and Greenland records for the last glacial to interglacial transition: a case study of Soppensee and NGRIP. Quat Int 2011, 246:145-156.

37. Dugmore AJ, Church MJ, Mairs K-A, McGovern TH, Perdikaris S, Vésteinsson O: Abandoned farms, volcanic impacts, and woodland management: revisiting pjórsárdalur, the "Pompeii Of Iceland". Arct Anthropol 2007, 44:1-11.

38. Dugmore AJ, Gisladóttir G, Simpson IA, Newton A: Conceptual models of 1200 years of icelandic soil erosion reconstructed using tephrochronology. J North Atlantic 2009, 2:1-18.

39. Dugmore AJ, Larsen G, Newton AJ: Tephrochronology and its Application to Late Quaternary Envirtonmental Reconstruction, with Special Reference to the North Atlantic Islands. In Tools for Constructing Chronologies: Crossing Disciplinary Boundaries. Edited by Buck CE, Millard A. London: Springer; 2004:173-188,

40. Edwards KJ, Dugmore AJ, Blackford JJ: Vegetational response to tephra deposition and land-use change in Iceland: a modern analogue and multiple working hypothesis approach to tephropalynology. Polar Record 2004, 40:113-120.

41. Dugmore AJ, Vésteinsson O: Black Sun, High Flame, and Flood: Volcanic Hazards in Iceland. In Surviving Sudden Environmental Change. Edited by Cooper J, Sheets PD. Boulder, CO: University of Colorado Press; 2012:67-90

42. Maschner HDG, Jordan JW: Catastrophic Events and Punctuated Culture Change: The Southern Bering Sea and North Pacific in a Dynamic Global System. In Time and Change. Archaeological and Anthropological Perspectives on the Long-Term in Hunter-Gatherer Societies. Edited by Papagianni D, Layton RH. Oxford: Oxbow; 2008:95-113.

43. Vanderhoek R, Nelson RE: Ecological Roadblocks on a Constrained Landscape: The Cultural Effects of Catastrophic Holocene Volcanism on the Alaska Peninsula, Southwest Alaska. In Living Under The Shadow. Cultural Impacts of Volcanic Eruptions. Edited by Grattan J, Torrence R. Walnut Creek, CA: Left Coast Press; 2007:133-152.

44. Dumond DE: Volcanism and History on the Northern Alaska Peninsula. Arct Anthropol 2004, 41:112-125.

45. Sheets PD: Responses to Explosive Volcanic Eruptions by Small to Complex Societies in Ancient Mexico and Central America. In Surviving Sudden Environmental Change. Edited by Cooper J, Sheets PD. Boulder, CO: University of Colorado Press; 2012:43-63.

46. Sheets PD: Armageddon to the Garden of Eden: Explosive Volcanic Eruptions and Societal Resilience in Ancient Middle America. In El Niño, Catastrophism, and Culture Change in Ancient America. Edited by Sandweiss D, Quilter J. Cambridge, MA: Harvard University Press; 2008:167-186. 
47. Siebe C, Abrams M, Macías JL, Obenholzer J: Repeated volcanic disasters in Prehispanic time at Popocatépetl, central Mexico: past key to the future? Geology 1996, 24:399-402.

48. Plunket $P$, Uruñuela $G$ : Social and cultural consequences of a late Holocene eruption of Popocatépetl in central Mexico. Quat Int 2006, 151:19-28.

49. Hall ML, Mothes PA: Volcanic impediments in the progressive development of pre-Columbian civilizations in the Ecuadorian Andes. $J$ Volcanol Geotherm Res 2008, 176:344-355.

50. Moseley ME: Modeling protracted drought, collateral natural disaster, and human responses in the Andes. In Catastrophe \& culture: the anthropology of disaster. Edited by Hoffman SM, Oliver-Smith A. Santa Fe, NM: School of American Research Press; 2002:187-212.

51. Petrie CA, Torrence R: Assessing the effects of volcanic disasters on human settlement in the Willaumez Peninsula, Papua New Guinea: a Bayesian approach to radiocarbon calibration. Holocene 2008, 18:729-744.

52. Torrence R, Neall VE, Boyd WE: Volcanism and historical ecology on the Willaumez Peninsula, Papua New Guinea. Pac Sci 2009, 63:507-535.

53. Neall VE, Wallace RC, Torrence R: The volcanic environment for 40,000 years of human occupation on the Willaumez Isthmus, West New Britain, Papua New Guinea. J Volcanol Geotherm Res 2008, 176:330-343.

54. Machida $\mathrm{H}$ : The stratigraphy, chronology and distribution of distal markertephras in and around Japan. Global Planet Change 1999, 21:71-94.

55. Machida M, Sugiyama S: The impact of the Kikai-Akahoya explosive eruptions on human societies. In Natural Disasters and Cultural Change. Edited by Torrence R, Grattan J. London: Routledge; 2002:313-325.

56. Matsufuji $\mathrm{K}$ : When were the earliest hominin migration to the Japanese islands. In Asian Paleoanthropology. From Africa to China and Beyond. Edited by Norton CJ, Braun DR. New York, NY: Springer; 2010:191-200.

57. Lowe DJ, Newnham RM, McCraw JD: Volcanism and early Maori society in new Zealand. In Natural Disasters and Cultural Change. Edited by Torrence R, Grattan J. London: Routledge; 2002:126-161.

58. Lowe DJ, Newnham RM, McFadgen BG, Higham TFG: Tephras and New Zealand Archaeology. J Archaeol Sci 2000, 27:859-870.

59. Kylander ME, Lind EM, Wastegard S, Lowemark L: Recommendations for using XRF core scanning as a tool in tephrochronology. Holocene 2012, 22:371-375

60. Turney CSM: Extraction of rhyolitic component of Vedde microtephra from minerogenic lake sediments. J Paleolimnol 1998, 19:199-206.

61. Blockley SPE, Pyne-O'Donnell SDF, Lowe JJ, Matthews IP, Stone A, Pollard AM, Turney CSM, Molyneux EG: A new and less destructive laboratory procedure for the physical separation of distal glass tephra shards from sediments. Quat Sci Rev 2005, 24:1952-1960.

62. Dörfler W, Feeser I, van den Bogaard C, Dreibrodt S, Erlenkeuser H, Kleinmann A, Merkt J, Wiethold J: A high-quality annually laminated sequence from Lake Belau, Northern Germany: revised chronology and its implications for palynological and tephrochronological studies. Holocene 2012, 22:1413-1426.

63. Semmel A, Terhorst B: The concept of the Pleistocene periglacial cover beds in central Europe: a review. Quat Int 2010, 222:120-128.

64. Dotterweich M, Kühn P, Tolksdorf JF, Müller S, Nelle O: Late Pleistocene to Early Holocene natural and human influenced sediment dynamics and soil formation in a 0-order catchment in SW-Germany (Palatinate Forest). Quat Int. in press.

65. Martini J: Recherches de tetombées volcanicques quaternaires dans le $\mathrm{S}$. E. de la France et la Suisse occidentale. Arch Sci 1971, 23:641-674.

66. Busschers FS, Kasse C, van Balen RT, Vandenberghe J, Cohen KM, Weerts HJT, Wallinga J, Johns C, Cleveringa P, Bunnik FPM: Late Pleistocene evolution of the Rhine-Meuse system in the southern North Sea basin: imprints of climate change, sea-level oscillation and glacio-isostacy. Quat Sci Rev 2007, 26:3216-3248.

67. Brendryen J, Haflidason H, Sejrup HP: Norwegian Sea tephrostratigraphy of marine isotope stages 4 and 5: prospects and problems for tephrochronology in the North Atlantic region. Quat Sci Rev 2010, 29:847-864.

68. Lane CS, Blockley SPE, Mangerud J, Smith VC, Lohne ØS, Tomlinson EL, Matthews IP, Lotter AF: Was the 12.1 ka Icelandic Vedde Ash one of a kind? Quat Sci Rev 2012, 33:87-99.

69. Livadie CA, Widemann F: Volcanology and Archaeology. Strasbourg: Council of Europe; 1990

70. Grattan J, Torrence R: Living Under The Shadow. Cultural Impacts of Volcanic Eruptions. Walnut Creek, CA: Left Coast Press; 2007.
71. Grattan J: Aspects of Armageddon: an exploration of the role of volcanic eruptions in human history and civilization. Quat Int 2006, 151:10-18.

72. Torrence R, Grattan J: Natural Disasters and Cultural Change. London: Routledge; 2002.

73. Daley TJ, Barber KE: Multi-proxy Holocene palaeoclimate records from Walton Moss, northern England and Dosenmoor, northern Germany, assessed using three statistical approaches. Quat Int 2012, 268:111-127.

74. Bokelmann K: Ein mesolithischer Wohnplatz im Dosenmoor bei Bordesholm, Kr. Rendsburg-Eckernförde. Offa 1973, 30:221-222.

75. Meurers-Balke J: Pollenanalytischer Befund bei dem mesolithischen Fundplatz im Dosenmoor, Kr. Rendsburg-Eckernförde. Offa 1973, 30:223-227.

76. van den Bogaard C, Schmincke H-U: Linking the North Atlantic to central Europe: a high-resolution Holocene tephrochronological record from northern Germany. J Quat Sci 2002, 17:3-20.

77. van den Bogaard C, Dörfler W, Sandgren P, Schmincke H-U: Correlating the holocene records: Icelandic tephra found in Schleswig-Holstein (Northern Germany). Naturwissenschaften 1994, 81:554-556.

78. Pyne-O'Donnell S: The taphonomy of Last Glacial-Interglacial Transition (LGIT) distal volcanic ash in small Scottish lakes. Boreas 2011, 40:131-145.

79. Hartz S: Kongemose-Kultur in Schleswig-Holstein. Offa 1985, 42:35-56.

80. Hartz S: Neue spätpaläolithische Fundplätze bei Ahrenshöft, Kreis Nordfriesland. Offa 1987, 44:5-52.

81. Hingst H: Steinzeitliche Siedlungsplätze in Ahrenshöft, Kr. Husum. Germania 1957, 35:371.

82. Clausen I: Neue Untersuchungen an späteiszeitlichen Fundplätzen der Hamburger Kultur bei Ahrenshöft. Kr. Nordfriesland. Ein Vorbericht. Archäologische Nachrichten aus Schleswig-Holstein 1998, 8:8-49.

83. Rust A: Die Alt- und Mittelsteinzeitlichen Funde von Stellmoor. Neumünster: Karl Wachholtz Verlag GmbH; 1943.

84. Rust A: Das steinzeitliche Rentierjägerlager Meiendorf. Neumünster: Karl Wachholtz Verlag GmbH; 1937

85. Stapert D: The Late Palaeolithic in the northern Netherlands. In L'Europe centrale et septentrionale au Tardiglaciaire. Actes de la Table-Ronde internationale de Nemours, 13-16 mai 1997. Edited by Valentin B, Bodu P, Christensen M. Paris: Mémoires du Musée de Préhistoire d'lle de France; 2000:175-195.

86. Kabacinski J, Sobkowiak-Tabaka I: The 'eastern extension' - New data on the Hamburgan in Poland. In A mind set on flint. Studies in honour of Dick Stapert. Edited by Niekus M, Barton RNE, Street M, Terberger T. Groningen: Barkhuis; 2012:217-234

87. Kabacinski J, Kobusiewicz M: New Hamburgian occupation in centralwestern Poland. In Man - Millenia - Environment. Studies in honour of Romulad Schild. Edited by Sulgostowska Z, Tomaszewski AJ. Warsaw: Institute of Archaeology and Ethnology, Polish Academy of Sciences; 2008:171-183.

88. Holm J, Rieck F: Die Hamburger Kultur in Dänemark. Archäologisches Korrespondenzblatt 1987, 17:151-168.

89. Riede F: Success and failure during the Late Glacial pioneer human recolonisation of southern Scandinavia. In Lateglacial and postglacial pioneers in northern Europe. Edited by Riede F, Tallavaara M. Oxford: Oxbow. in press: $\mathrm{XX}-\mathrm{XX}$

90. Ballin TB, Saville A, Tipping R, Ward T: An Upper Palaeolithic flint and chert assemblage from Howburn Farm, south Lanarkshire, Scotland: first results. Oxf J Archaeol 2010, 29:323-360.

91. Grimm SB, Weber M-J: The chronological framework of the Hamburgian in the light of old and new ${ }^{14} \mathrm{C}$ dates. Quartär 2008, 55:17-40.

92. Weber M-J, Grimm SB: Dating the Hamburgian in the Context of Lateglacial Chronology. In Chronology and Evolution within the Mesolithic of North-West Europe: Proceedings of an International Meeting, Brussels, May 30th-June 1st 2007. Edited by Crombé P, Van Strydonck M, Sergant J, Bats M, Boudin M. Newcastle: Cambridge Scholars Publishing; 2009:3-21.

93. Housley RA, Lane CS, Cullen VL, Weber MJ, Riede F, Gamble CS, Brock F: Icelandic volcanic ash from the Late-glacial open-air archaeological site of Ahrenshöft LA 58 D, North Germany. J Archaeol Sci 2012, 39:708-716.

94. Weber M-J, Clausen I, Housley RA, Miller CE, Riede F, Usinger H: New information on the Havelte Group site Ahrenshöft LA 58 D (Nordfriesland, Germany) - Preliminary results of the 2008 fieldwork. Quartär 2010, 57:7-24.

95. Schmincke H-U: Environmental impacts of the Lateglacial eruption of the Laacher See Volcano, 12.900 cal BP. In 150 years of Neanderthal Discoveries. Edited by von Koenigswald W, Litt T. Bonn: Terra Nostra; 2006:149-153. 
96. Schmincke H-U, Park C, Harms E: Evolution and environmental impacts of the eruption of Laacher See Volcano (Germany) 12,900 a BP. Quat Int 1999, 61:61-72.

97. Oppenheimer C: Eruptions that shook the world. Cambridge: Cambridge University Press; 2011.

98. Freundt A, Schmincke H-U: Lithic-enriched segregation bodies in pyroclastic flow deposits of Laacher See Volcano (East Eifel, Germany). Volcanol Geotherm Res 1985, 25:193-224.

99. Freundt A, Schmincke HU: Hierarchy of facies of pyroclastic flow deposits generated by Laacher See-Type eruptions. Geology 1985, 13:278-281.

100. Harms E, Gardner JE, Schmincke HU: Phase equilibria of the Lower Laacher See Tephra (East Eifel, Germany): constraints on pre-eruptive storage conditions of a phonolitic magma reservoir. J Volcanol Geotherm Res 2004, 134:125-138.

101. Harms E, Schmincke H-U: Volatile composition of the phonolitic Laacher See magma (12,900 yr BP): implications for syn-eruptive degassing of $\mathrm{S}$ $\mathrm{F}, \mathrm{Cl}$ and $\mathrm{H}_{2} \mathrm{O}$. Contrib Mineral Petrol 2000, 138:84-98.

102. Schmincke H-U: Volcanism. Berlin: Springer; 2004.

103. Schmincke HU, Fisher RV, Waters AC: Antidune and chute and pool structures in base surge deposits of Laacher-See area, Germany. Sedimentology 1973, 20:553-574.

104. Schumacher R, Schmincke H-U: Internal structure and occurrence of accretionary Lapilli - a case-study at Laacher See volcano. Bull Volcanol 1991, 53:612-634.

105. Schumacher R, Schmincke H-U: The lateral facies of ignimbrites at Laacher See volcano. Bull Volcanol 1990, 52:271-285

106. van den Bogaard P, Schmincke H-U, Freundt A, Park C: Evolution of Complex Plinian Eruptions: the Late Quaternary Laacher See Case History. In Thera and the Aegean World III. Volume 2: Earth Sciences. Edited by Hardy DA, Keller J, Galanopoulos VP, Flemming NC, Druitt TH. London: The Thera Foundation; 1990:463-483.

107. Wörner G, Schmincke H-U: Petrogenesis of the Zoned Laacher See tephra. J Petrol 1984, 25:836-851

108. Wörner G, Schmincke H-U: Mineralogical and chemical Zonation of the Laacher See tephra sequence (East Eifel, W. Germany). J Petrol 1984, 25:805-835.

109. van den Bogaard $\mathrm{P}$, Schmincke H-U: The eruptive center of the Late Quaternary Laacher See Tephra. Geol Rundsch 1984, 73:933-980.

110. Pyle DM: Sizes of volcanic eruptions. In Encyclopedia of Volcanoes. Edited by Sigurdsson H, Houghton BF, McNutt SR, Rymer H, Stix J. San Diego, CA: Academic Press; 2000:263-270.

111. Park C, Schmincke H-U: Lake formation and catastrophic dam burst during the late pleistocene Laacher See eruption (Germany). Naturwissenschaften 1997, 84:521-525.

112. Park C, Schmincke H-U: Apokalypse im Rheintal. Spektrum der Wissenschaften 2009, 2009:78-87.

113. Hijma MP, Cohen KM, Roebroeks W, Westerhoff WE, Busschers FS: Pleistocene Rhine-Thames landscapes: geological background for hominin occupation of the southern North Sea region. J Quat Sci 2012, 27:17-39.

114. Baales M, Bittmann F, Kromer B: Verkohlte Bäume im Trass der Laacher See-Tephra bei Kruft (Neuwieder Becken). Ein Beitrag zur Datierung des Laacher See-Ereignisses und zur Vegetation der Alleröd-Zeit am Mittelrhein. Archäologisches Korrespondenzblatt 1999, 28:191-204.

115. Street M: Ein Wald der Allerödzeit bei Miesenheim, Stadt Andernach (Neuwieder Becken). Archäologisches Korrespondenzblatt 1986, 16:13-22

116. Baales M, von Berg A: Tierfährten in der allerödzeitlichen Vulkanasche des Laacher See-Vulkans bei Mertloch, Kreis Mayen-Koblenz. Archäologisches Korrespondenzblatt 1997, 27:1-12

117. von Berg A: Allerödzeitliche Feuerstellen unter dem Bims im Neuwieder Becken (Rheinland-Pfalz). Archäologisches Korrespondenzblatt 1994, 24:355-365.

118. Baales M: Final Palaeolithic environment and archaeology in the Central Rhineland (Rhineland-Palatinate, western Germany): conclusions of the last 15 years of research. l'Anthropologie 2006, 110:418-444.

119. Brauns R: Bimssteine auf primärer Lagerstätte von Görzhausen bei Marburg. Zeitschrift der deutschen geologischen Gesellschaft 1886, 38:234-236.

120. van den Bogaard P, Schmincke H-U: Aschelagen als quatäre Zeitmarken in Mitteleuropa. Die Geowissenschaften 1988, 6:75-84

121. Grote K: Das Buntsandsteinabri Bettenroder Berg IX im Reinhäuser Wald bei Göttingen - Paläolithikum und Mesolithikum. Archäologisches Korrespondenzblatt 1990, 20:137-147.
122. Mania D: Ascheregen vor 13000 Jahren im Elbe-Saalegebiet. Praehistoria Thuringica 2003, 9:51-79.

123. Riede F: The loss and re-introduction of bow-and-arrow technology: a case study from the Southern Scandinavian Late Palaeolithic. Lithic Technology 2009, 34:27-45

124. Riede F: The Laacher See-eruption (12,920 BP) and material culture change at the end of the Allerød in Northern Europe. J Archaeo/ Sci 2008, 35:591-599.

125. Riede F: Tephrochronologische Nachuntersuchungen am endpaläolithischen Fundplatz Rothenkirchen, Kreis Fulda. Führte der Ausbruch des Laacher See-Vulkans (10966 v. Chr.) zu einer anhaltenden Siedlungslücke in Hessen. Jahrbuch des nassauischen Vereins für Naturkunde 2012, 133:47-68.

126. Riede F, Bazely O: Testing the 'Laacher See hypothesis': a health hazard perspective. J Archaeol Sci 2009, 36:675-683.

127. Dev S, Riede F: Quantitative functional analysis of Late Glacial projectile points from northern Europe. Lithics 2012, 33:40-55.

128. Riede F, Edinborough $\mathrm{K}$ : Bayesian radiocarbon models for the cultural transition during the Allerød in southern Scandinavia. J Archaeol Sci 2012, 39:744-756.

129. Riede F, Wheeler JM: Testing the 'Laacher See hypothesis': tephra as dental abrasive. J Archaeo/ Sci 2009, 36:2384-2391.

130. Waldmann W, Jöris O, Baales M: Nach der Flut - Ein spätallerødzeitlicher Rückenspitzen-Fundplatz bei Bad Breisig. Mit einem Beitrag von Julian Wiethold. Archäologisches Korrespondenzblatt 2001, 31:173-184.

131. Pirson S, Flas D, Abrams G, Bonjean D, Court-Picon M, Di Modica K, Draily C, Damblon F, Haesaerts P, Miller R, Rougier H, Toussaint M, Semal P: Chronostratigraphic context of the Middle to Upper Palaeolithic transition: Recent data from Belgium. Quat Int 2012, 259:78-94.

132. Dewez MC: Nouvelles recherches à la Grotte du Coléoptère à Bomal-sur -Ourthe (province du Luxembourg). Rapport provisoire de la première campagne de fouille. Helinium 1975, XV:105-133.

133. Baales $M$, Jöris $O$ : Between North and South - a site with backed points from the final Allerod: Bad Breisig, Kr. Ahrweiler (Central Rhineland, Germany). l'Anthropologie 2002, 106:249-267.

134. Bolus M: Die Siedlungsbefunde des späteiszeitlichen Fundplatzes Niederbieber (Stadt Neuwied): Ausgrabungen 1981-1988; mit Beiträgen von Gabriele Roth, Siegfried Stephan, Rolf C. Rottländ. Bonn: Verlag Rudolf Habelt GmbH; 1992.

135. Loew S: Der Federmesser-Fundplatz Rüsselsheim 122 am unteren Main (Hessen). Archäologisches Korrespondenzblatt 2005, 35:143-158.

136. Fruth H-J: Der spätpaläolithische Fundplatz Mühlheim-Dietesheim, Kreis Offenbach. Fundberichte aus Hessen 1994, 22(23):1-67.

137. Grote K: Die Abris im südlichen Leinebergland bei Göttingen. Archäologische Befunde zum Leben unter Felsschutzdächern in urgeschichtlicher Zeit. Oldenburg: Isensee Verlag; 1994.

138. Altermann M, Mania D: Zur Datierung von Böden im mitteldeutschen Trockengebiet mit Hilfe quartärgeologischer und urgeschiclitlicher Befunde. Archives of Agronomy and Soil Science 1968, 12:539-557.

139. Knuth G, Thomae M: Zur Tephra im Alleröd bei Schadeleben und Krumpa in Sachsen-Anhalt. Hallesches Jahrbuch für Geowissenschaften 2003, 25:81-90.

140. Toepfer V: Paläolithische Fundstätten am ehemaligen AscherslebenerGaterslebener See. Ausgrabungen \& Funde 1965, 10:3-10.

141. Newton AJ: Tephrabase. a tephrochronological database. Quaternary Newsletter 1996, 78:8-13.

142. Newton AJ, Dugmore AJ, Gittings BM: Tephrabase: tephrochronology and the development of a centralised European database. J Quat Sci 2007, 22:737-743.

143. Kobusiewicz M: Tanged Point Cultures of Greater Poland 25 Years from the First Approach. In Tanged Point Cultures in Europe. Read at the International Archaeological Symposium. Lublin, September, 13-16, 1993. Edited by Kozlowski SK, Gurba J, Zaliznyak LL. Lublin: Maria CurieSklodowska University Press; 1999:110-120.

144. Szymzcak K: Late glacial in Poland - cultural differentiation. In L'Europe centrale et septentrionale au Tardiglaciaire. Mémoires du Musée de Préhistoire d'lle-de-France no 7, Nemours. Edited by Bodu P, Christensen M, Valentin B. Nemours: APRAIF; 2000:273-285.

145. Zaliznyak LL: Tanged Point Cultures in the Western Part of Eastern Europe. In Tanged Point Cultures in Europe. Read at the International Archaeological Symposium. Lublin, September, 13-16, 1993. Edited by Kozlowski SK, Gurba J, Zaliznyak LL. Lublin: Maria Curie-Sklodowska University Press; 1999:202-218.

146. Hannon GE, Bradshaw RHW: Impacts and timing of the first human settlement on vegetation of the Faroe Islands. Quatern Res 2000, 54:404-413. 
147. Diamond JM: Intra-Island and Inter-Island Comparisons. In Natural Experiments of History. Edited by Diamond JM, Robinson JA. Cambridge, MA: Belknap Press; 2010:120-141.

148. Rolett B, Diamond J: Environmental predictors of pre-European deforestation on Pacific islands. Nature 2004, 431:443-446.

149. Bevan A, Conolly J, Colledge S, Frederick C, Palmer C, Siddall R, Stellatou A: The long-term ecology of agricultural terraces and enclosed fields from Antikythera, Greece. Hum Ecol 2013, 41:255-272

150. Hannon GE, Wastegård S, Bradshaw E, Bradshaw RHW: Human impact and landscape degradation on the Faroe Islands. Biol Environ: Proceddings of the Royal Irish Academy 2001, 101B:129-139.

151. Wastegård S, Björck S, Grauert M, Hannon GE: The Mjáuvøtn tephra and other Holocene tephra horizons from the Faroe Islands: a link between the Icelandic source region, the Nordic Seas, and the European continent. Holocene 2001, 11:101-109.

152. Grönvold K, Óskarsson N, Johnsen SJ, Clausen HB, Hammer CU, Bond G, Bard E: Ash layers from Iceland in the Greenland GRIP ice core correlated with oceanic and land sediments. Earth Planet Sci Lett 1995, 135:149-155.

153. Lawson I, Church M, McGovern T, Arge S, Woollet J, Edwards K, GathorneHardy F, Dugmore A, Cook G, Mairs K-A, Thomson A, Sveinbjarnardótti G: Historical ecology on Sandoy, Faroe Islands: palaeoenvironmental and archaeological perspectives. Hum Ecol 2005, 33:651-684.

154. Balascio NL, Wickler S, Narmo LE, Bradley RS: Distal cryptotephra found in a Viking boathouse: the potential for tephrochronology in reconstructing the Iron Age in Norway. J Archaeol Sci 2011, 38:934-941.

155. Stylegar F-A, Grimm O: Boathouses in Northern Europe and the North Atlantic. Int J Naut Archaeol 2005, 34:253-268.

156. Myrhe B: Boathouses as Indicators of Political Organization. Nor Archaeol Rev 1985, 18:37-60.

157. Myrhe B: Boathouses and naval organisation. In Military aspects of Scandinavian society in a European perspective, AD 1-1300: Papers from an International Research Seminar at the Danish National Museum, Copenhagen 2-4 May 1996. Edited by Nørgård Jørgensen A, Clausen BL. Copenhagen: National Museum of Denmark; 1997:169-183.

158. Wickler S, Nilsen G: Pre-Modern Boathouses: a maritime perspective from northern Norway. Int J Naut Archaeol 2012, 41:106-119.

159. Pilcher JR, Bradley RS, Francus P, Anderson L: A Holocene tephra record from the Lofoten Islands, Arctic Norway. Boreas 2005, 34:136-156.

160. Balascio NL, Zhang Z, Bradley RS, Perren B, Dahl SO, Bakke J: A multi-proxy approach to assessing isolation basin stratigraphy from the Lofoten Islands, Norway. Quatern Res 2011, 75:288-300.

161. Beierle B, Bond J: Density-induced settling of tephra through organic lakesediments. J Paleolimnol 2002, 28:433-440.

162. Witham CS: Volcanic disasters and incidents: a new database. J Volcanol Geotherm Res 2005, 148:191-233.

163. Siebert L, Simkin T, Kimberly P: Volcanoes of the world. Washington, DC: Smithsonian Institution; 2010

164. Thorarinsson S: On the Damage Caused by Volcanic Eruptions with Special Reference to Tephra and Gases. In Volcanic Activity and Human Ecology. Edited by Sheets PD, Grayson DK. London: Academic Press; 1979:125-160.

165. García-Acosta V: Historical disaster research. In Catastrophe \& culture: the anthropology of disaster. Edited by Hoffman SM, Oliver-Smith A. Santa Fe, NM: School of American Research Press; 2002:49-66.

166. Chester DK: Volcanoes, society, and culture. In Volcanoes and the Environment. Edited by Martí J, Ernst GGJ. Cambridge: Cambridge University Press; 2005:404-439.

167. Turner BL, Kasperson RE, Matson PA, McCarthy JJ, Corell RW, Christensen L, Eckley N, Kasperson JX, Luers A, Martello ML, Polsky C, Pulsipher A, Schiller A: A framework for vulnerability analysis in sustainability science. Proc Natl Acad Sci 2003, 100:8074-8079.

168. Plunkett G: Hekla 3, environmental downturn and Irish Late Bronze Age hillfort connections revisited. Emania 2006, 20:55-60.

169. Gräslund B: Fimbulvintern, Ragnarök och klimatkrisen år 536-537 e. Kr. Saga och Sed 2007, 2008:93-123.

170. Gräslund B, Price N: Twilight of the gods? The 'dust veil event' of AD 536 in critical perspective. Antiquity 2012, 86:428-443.

171. McCormick M: Karl der Große und die Vulkane: Naturwissenschaft, Klimageschichte und Mittelalterforschung. Ethnographisch-archäologische Zeitschrift 2008, 49:129-145.

172. McCormick M, Dutton PE, Mayewski PA: Volcanoes and the climate forcing of Carolingian Europe, A.D. 750-950. Speculum 2007, 82:865-895.
173. Buckland PC, Dugmore AJ, Edwards KJ: Bronze Age myths? Volcanic activity and human response in the Mediterranean and North Atlantic regions. Antiquity 1997, 71:581-593.

174. Hulse EL, Keeler DM, Zubrow EBW, Korosec GJ, Ponkratova IY, Curtis C: A preliminary report on archaeological fieldwork in the Kamchatka Region of Russia. Siberica 2011, 10:48-74.

175. Fedele FG: Fossil Volcanism and Archaeology: the North Yemen Highlands. In Volcanology and Archaeology. Edited by Livadie CA, Widemann F. Strasbourg: Council of Europe; 1990:11-23.

176. Driessen J, MacDonald CF: The eruption of the Santorini volcano and its effects on Minoan Crete. In The Archaeology of Geological Catastrophes. Edited by McGuire WJ, Griffiths DR, Hancock PL, Stewart IS. London: Geological Society; 2000:81-94.

177. Edwards KJ, Buckland P, Blackford JJ, Dugmore A, Sadler JP: The Impact of Tephra: Proximal and Distal Studies of Icelandic Eruptions. In Environmental Change in Iceland. Edited by Stötter J, Wilhelm F. Munich: GEOBUCH; 1994:79-100.

178. Fitzhugh B: Hazards, Impacts, and Resilience among Hunter-Gatherers of the Kuril Islands. In Surviving Sudden Environmental Change. Edited by Cooper J, Sheets PD. Boulder, CO: University of Colorado Press; 2012:19-42.

179. Moseley ME: Convergent catastrophe: Past patterns and future implications of collateral natural disasters in the Andes. In The Angry Earth. Disaster in Anthropological Perspective. Edited by Oliver-Smith A, Hoffman SM. London: Routledge; 1999:59-71.

180. Pyne-O'Donnell SDF, Hughes PDM, Froese DG, Jensen BJL, Kuehn SC, Mallon G, Amesbury MJ, Charman DJ, Daley TJ, Loader NJ, Mauquoy D, Street-Perrott FA, Woodman-Ralph J: High-precision ultra-distal Holocene tephrochronology in North America. Quat Sci Rev 2012, 52:6-11.

181. Baillie MGL: Suck-in and smear: two related chronological problems for the 90s. J Theor Achaeology 1991, 2:12-16.

182. King G, Bailey GN: Tectonics and human evolution. Antiquity 2006, 60:265-285.

183. Feibel CS: Tephrostratigraphy and geological context in paleoanthropology. Evol Anthropol 1999, 8:87-100.

184. Ambrose SH: Did the super-eruption of Toba cause a human population bottleneck? Reply to Gathorne-Hardy and Harcourt-Smith. J Hum Evol 2003, 45:231-237.

185. Ambrose SH: Late Pleistocene human population bottlenecks, volcanic winter and the differentiation of modern humans. J Hum Evol 1998, 34:623-651.

186. Gathorne-Hardy FJ, Harcourt-Smith WE: The super-eruption of Toba, did it cause a human bottleneck? J Hum Evol 2003, 45:227-230.

187. Petraglia M, Korisettar R, Boivin N, Clarkson C, Ditchfield P, Jones S, Koshy J, Lahr MM, Oppenheimer C, Pyle D, Roberts R, Schwenninger J-L, Arnold L, White K: Middle Paleolithic Assemblages from the Indian Subcontinent Before and After the Toba Super-Eruption. Science 2007, 316:114-116.

188. Rampino MR, Ambrose SH: Volcanic winter in the Garden of Eden: The Toba supereruption and the late Pleistocene human population crash. In Volcanic Hazards and Disasters in Human Antiquity. Edited by McCoy FW, Heiken G. Boulder, CO: Geological Society of America; 2000:71-82.

189. Rampino MR, Self S: Bottleneck in human evolution and the Toba eruption. Science 1955, 1993:262

190. Fedele FG, Giaccio B, Isaia R, Orsi G, Carroll M, Scaillet B: The Campanian Ignimbrite Factor: Towards a Reappraisal of the Middle to Upper Palaeolithic 'Transition'. In Living Under The Shadow. Cultural Impacts of Volcanic Eruptions. Edited by Grattan J, Torrence R. Walnut Creek, CA: Left Coast Press; 2007:19-41.

191. Giaccio B, Hajdas I, Peresani M, Fedele FG, Isaia R: The Campanian Ignimbrite Tephra and its Relevance for the Timing of the Middle to Upper Palaeolithic Shift. In When Neanderthals and Modern Humans Met. Edited by Conard NJ. Tübingen: Kerns Verlag; 2006:343-375

192. Grattan J, Torrence R: Beyond Gloom and Doom: The Long-Term Consequences of Volcanic Disasters. In Living Under The Shadow. Cultural Impacts of Volcanic Eruptions. Edited by Grattan J, Torrence R. Walnut Creek, CA: Left Coast Press; 2007:1-18.

193. Cashman KV, Giordano G: Volcanoes and human history. J Volcanol Geotherm Res 2008, 176:325-329.

194. Riede F: Volcanic activity. In Encyclopedia of Global Archaeology. Edited by Smith C. London: Springer. in press.

doi:10.1186/2050-7445-1-15

Cite this article as: Riede and Thastrup: Tephra, tephrochronology and archaeology - a (re-)view from Northern Europe. Heritage Science 2013 $1: 15$. 